\title{
Penerapan Model Pembelajaran Kooperatif Tipe Jigsaw Sebagai Upaya Meningkatkan Prestasi Belajar Muatan PKn Peserta Didik di Kelas VI SDN 96/X Rantau Indah Semester Ganjil Tahun Ajaran 2021/2022
}

\author{
Maryatun \\ SDN 96/X Rantau Indah \\ SK 3 Dusun Eka Jaya, Rantau Indah, Kabupaten Tanjung Jabung Timur, Jambi \\ maryatun1234@gmail.com
}

\begin{abstract}
This study aims to describe and obtain information on improving learning outcomes for Civics content through the Jigsaw Cooperative Learning Model. This research is classroom action research which consists of two cycles, each cycle consists of two meetings. Each meeting consists of four stages, namely planning, implementation, observation, and reflection. The subjects of this study were students of class VI SDN 96/X Rantau Indah, totaling 12 people. This research was conducted in the odd semester of the 2021/2022 academic year. Data collection techniques using tests, observations, and documentation. Data were analyzed using percentages. The results showed that the Jigsaw Type Cooperative Model could improve the learning achievement of Class VI students of SDN 96/X Rantau Indah.
\end{abstract}

Keywords: Civic Education Learning Outcomes, Jigsaw

\begin{abstract}
Abstrak
Penelitian ini bertujuan untuk mendeskripsikan dan mendapatkan informasi peningkatan hasil belajar Muatan PKn melalui Model Pembelajaran Kooperatif Tipe Jigsaw. Penelitian ini merupakan penelitian tindakan kelas yang terdiri dari dua siklus masing-masing siklus terdiri dari dua kali pertemuan. Masing-masing petemuan terdiri dari empat tahapan yaitu perencanaan, pelaksanaan, observasi dan refleksi. Subjek penelitian ini adalah peserta didik kelas VI SDN 96/X Rantau Indah yang berjumlah 12 orang. Penelitian ini dilaksanakan pada semseter ganjil tahun ajaran 2021/2022. Teknik pengumpulan data menggunakan tes, observasi, dan dokumentasi. Data dianalisis menggunakan persentase. Hasil penelitian menunjukkan bahwa melalui Model Kooperatif Tipe Jigsaw dapat meningkatkan prestasi belajar Muatan PKn peserta didik kelas VI SDN 96/X Rantau Indah.
\end{abstract}

Kata kunci: hasil belajar PKn, Jigsaw

Copyright (c) 2021 Maryatun

Corresponding author: Maryatun

Email Address: maryatun1234@gmail.com (SK 3 Dusun Eka Jaya, Rantau Indah, Jambi)

Received 10 January 2022, Accepted 20 January 2022, Published 16 February 2022

\section{PENDAHULUAN}

Pendidikan mempunyai peran penting dalam pengembangan potensi diri pada setiap individu. Hal ini sesuai dengan UU Sisdiknas No. 20 Tahun 2013 Bab 1 pasal 1 yang menyebutkan bahwa pendidikan adalah usaha sadar dan terencana untuk mewujudkan suasana belajar dan proses pembelajaran agar peserta didik secara aktif mengembangkan potensi dirinya (BSNP, 2006). Pendidikan adalah suatu proses kegiatan interaksi antara guru dengan peserta didik yang bertujuan meningkatkan perkembangan peserta didik (Dimyati dan Mudjiono, 2009: 5-7).

Proses pembelajaran di sekolah melibatkan guru sebagai pendidik dan peserta didik sebagai peserta didik. Proses pembelajaran dikatakan baik jika kegiatannya dapat merangsang peserta didik dalam mengembangkan segala potensi dirinya untuk meraih prestasi. Kegiatan belajar tersebut dapat terwujud dengan menerapkan pembelajaran yang aktif, kreatif, efektif, dan menyenangkan (PAKEM). 
Utami (2010: 23) menjelaskan PAKEM adalah satu pendekatan dalam pembelajaran yang dianggap efektif, karena dapat membentuk otonomi diri peserta didik. Proses pembelajaran adalah suatu kegiatan interaksi antara pendidik yang melaksanakan tugas pembelajaran peserta didik melaksanakan tugas belajar. Proses kegiatan belajar mengajar ini bukan hanya penyampaian pesan berupa materi pelajaran saja, melainkan penanaman sikap dan nilai pada diri peserta didik yang sedang belajar.

PKn merupakan salah satu mata pelajaran yang tidak hanya mengajarkan tentang pengetahuan saja tetapi juga dapat membentuk karakter peserta didik. Utami (2010: 66-68) mengemukakan tujuan pelajaran PKn adalah agar peserta didik memiliki kemampuan untuk berpikir kritis, rasional, dan kreatif dalam menanggapi isu kewarganegaraan; berpartisipasi secara aktif dan bertanggung jawab, dan bertindak secara cerdas dalam kegiatan bermasyarakat, berbangsa, dan bernegara, serta anti korupsi; berkembang secara positif dan demokratis untuk membentuk diri berdasarkan karakterkarakter masyarakat Indonesia agar dapat hidup bersama dengan bangsa-bangsa lainnya; dan berinteraksi dengan bangsa- bangsa lain dalam percaturan dunia secara langsung dengan memanfaatkan teknologi informasi dan komunikasi. Seorang peserta didik tidak hanya dibimbing untuk memiliki kualitas intelektual tetapi juga memiliki karakter-karakter masyarakat Indonesia yang demokratis dan dapat hidup bersama dengan bangsa-bangsa lainnya (Utami, 2010: 67).

Pelajaran PKn juga menuntut peran aktif peserta didik, karena pada dasarnya peserta didik memiliki rasa ingin tahu yang sangat besar dan kuat. Hal ini ditunjukkan oleh kecenderungan heran dan kagum pada hal-hal yang baru dan menantang (Purnomo, 2006: 2). Keaktifan peserta didik dalam pembelajaran PKn dapat diwujudkan dengan menerapkan pendekatan, model, atau metode belajar yang menarik dan inovatif dalam proses pembelajaran. Keaktifan belajar peserta didik dalam proses pembelajaran dapat menumbuhkan minat untuk belajar dalam diri peserta didik, yangakan berpengaruh dalam proses pembelajaran. Slameto (2010: 180), mengungkapkan bahwa peserta didik yang memiliki minat yang tinggi dalam proses pembelajaran akan cenderung termotivasi dari dalam dirinya untuk mengikuti proses pembelajaran dengan baik dan antusias, sebaliknya apabila minat peserta didik dalam proses pembelajaran rendah akan ditunjukkan dengan perilaku yang mengarah pada hal-hal yang negatif, misalnya melamun, berbicara dengan teman, bercanda dengan teman, dan tidak memperhatikan guru yang sedang mengajar. Keaktifan merupakan modal awal untuk mendorong peserta didik melakukan suatu kegiatan belajar.

Silberman (Widharyanto, 2002: 63) menjelaskan bahwa pembelajaran yang berorientasi pada peserta didik (student centered learning) adalah pembelajaran yang mengaktifkan peserta didik dan peserta didik banyak melakukan aktivitas, peserta didik menggunakan otaknya untuk mengkaji ideide, memecahkan masalah, dan menerapkan apa yang mereka pelajari. Ada beberapa jenis model pembelajaran kooperatif yang dapat digunakan untuk meningkatkan keaktifan dan prestasi belajar peserta didik antara lain, model Group Investigation(GI), model jigsaw, dan model Cooperatif Integrated reading and Compostion (CIRC). Model Group Investigation(GI) merupakan model pembelajaran yang memerlukan norma dan struktur kelas yang yang mengajarkan peserta didik 
Penerapan Model Pembelajaran Kooperatif Tipe Jigsaw Sebagai Upaya Meningkatkan Prestasi Belajar Muatan PKn Peserta Didik di Kelas VI SDN 96/X Rantau Indah Semester Ganjil Tahun Ajaran 2021/2022, Maryatun

keterampilan komunikasi dan proses kelompok yang benar (Uno dan Mohamad, 2012: 109). Model jigsaw adalah model pembelajaran yang menghendaki peserta didik belajar melalui kelompok, yang didesain untuk meningkatkan rasa tanggung jawab peserta didik terhadap pembelajarannya sendiri dan juga pembelajaran orang lain dimana peserta didik tidak hanya mempelajari materi yang diberikan, tetapi mereka juga harus siap memberikan dan mengajarkan materi tersebut kepada kelompoknya, sehingga baik kemampuan secara kognitif maupun sosial peserta didik sangat diperlukan(Uno dan Mohamad, 2012: 98).

Masalah kurangnya keaktifan peserta didik dalam pembelajaran menyebabkan rendahnya prestasi belajar peserta didik. Hal tersebut menjadi dasar dalam menentukan tindakan untuk meningkatkan keaktifan peserta didik dalam pembelajaran. Solihatin (2007: 23) mengungkapkan dengan peserta didik aktif maka peserta didik akan berusaha untuk menggali informasi lebih dalam agar informasi yang mereka peroleh itu dapat benar-benar mereka pahami sehingga tujuan dari proses belajar dapat tercapai dengan baik.

Berdasarkan hasil observasi yang dilakukan pada peserta didik kelas VI SDN 96/X Rantau Indah dapat disimpulkan bahwa saat guru masuk kelas jam pelajaran PKn peserta didik banyak yang lari-lari dalam kelas atau teriak-teriak, ngobrol dengan temannya, dan saling lempar-lemparan kertas. Observasi juga menunjukkan bahwa peserta didik yang menjawab atau memberi tanggapan dari pertanyaan guru hanya peserta didik tertentu saja. Peserta didik juga tidak berinisiatif untuk mencatat materi, apabila guru tidak menyuruh.

Tindakan peneliti untuk mengatasi masalah keaktifan dan prestasi belajar PKn adalah dengan menerapkan model pembelajaran kooperatif tipe jigsaw. Peneliti memilih menggunakan model pembelajaran kooperatif tipe jigsaw karena dapat meningkatkan keaktifan dan prestasi belajar peserta didik dan telah dibuktikan oleh penelitian yang dilakukan oleh Utami (2010) dan Sari Astuti (2013).

Peneliti menggunakan model pembelajaran kooperatif tipe jigsaw untuk meningkatkan keaktifan dan prestasi belajar PKn pada peserta didik VI SDN 96/X Rantau Indah. Model pembelajaran kooperatif tipe jigsaw dipilih karena di dalam pembelajaran dengan menggunakan tipe jigsaw, dapat meningkatkan hasil belajar, meningkatkan daya ingat, mendorong tumbuhnya motivasi intrinsik (kesadaran individu), meningkatkan hubungan antar manusia yang heterogen, meningkatkan sikap anak yang positif terhadap guru, meningkatkan harga diri anak, meningkatkan penyesuaian sosial yang positif, dan meningkatkan keterampilan hidup bergotong royong (Rusman, 2011: 219). Model pembelajaran kooperatif tipe jigsaw dalam pembelajaran diharapkan dapat meningkatkan keaktifan dan prestasi belajar peserta didik.

Belajar adalah key term, "istilah kunci” yang paling vital dalam setiap usaha pendidikan, sehingga tanpa belajar sesungguhnya tak pernah ada pendidikan (Syah, 2003: 59). Belajar merupakan serangkaian aktivitas yang dapat menimbulkan adanya perubahan perilaku. Perubahan perilaku tersebut dihasilkan karena adanya respon yang diperkuat (Suparno, 2001: 2). Bloom (Suparno, 2001: 6) membagi belajar ke dalam tingkatan-tingkatan yang disebut sebagai ranah kognitif, afektif, dan 
psikomotorik. Pembagian tingkatan-tingkatan dalam belajar tersebut sejalan dengan pengertian belajar menurut Dimyati (2009: 15) yaitu suatu kegiatan individu yang menggunakan ranah kognitif, psikomotorik, dan afektif. Akibat belajar tersebut kemampuan kognitif, psikomotorik, dan afektif semakin bertambah.

Keaktifan berasal dari kata aktif yang dalam KBBI (2008: 31) mengandung arti giat (bekerja, berusaha), sedangkan keaktifan merupakan kegiatan atau kesibukan. Jadi, keaktifan peserta didik dapat dikatakan sebagai suatu kegiatan yang dilakukan oleh peserta didik untuk memahami materi pelajaran. Sardiman (2001: 98) mengungkapkan bahwa keaktifan adalah kegiatan yang bersifat fisik maupun mental, yaitu berbuat dan berpikir sebagai suatu rangkaian yang tidak dapat dipisahkan. Thorndike (Dimyati dan Mudjiono, 2009: 45) mengemukakan keaktifan belajar peserta didik dalam belajar dengan hukum "law of exercise"-nya berkenaan dengan prinsip keaktifan mengemukakan bahwa individu merupakan "manusia belajar yang aktif selalu ingin tahu".

Pembelajaran menurut Jihad (20012: 18) adalah suatu proses yang mengandung serangkaian perbuatan guru dan peserta didik atas dasar hubungan timbal balik yang berlangsung dalam situasi edukasi untuk mencapai tujuan tertentu. Pembelajaran merupakan suatu proses yang terdiri dari kombinasi dua aspek yaitu belajar, yang berorientasi pada apa yang harus dilakukan oleh guru sebagai pemberi pelajaran. Pembelajaran pada dasarnya merupakan proses komunikasi antara peserta didik dan pendidik dalam rangka perubahan sikap.

Pembelajaran kooperatif menurut Sanjaya (2006: 240) merupakan model pembelajaran dengan menggunakan sistem pengelompokkan atau sistem kecil, yaitu antara 4 sampai enam orang yang mempunyai latar belakang kemampuan akademik, jenis kelamin, ras, atau suku yang berbeda (heterogen). Sugiyanto (2010: 37) mengemukakan pengertian pembelajaran kooperatif adalah pendekatan pembelajaran yang berfokus pada penggunaan kelompok kecil peserta didik untuk bekerjasama dalam memaksimalkan kondisi belajar untuk mencapai tujuan belajar. Pembelajaran kooperatif menurut Scott (Lie, 2007: 18) adalah suatu proses penciptaan lingkungan pembelajaran kelas yang memungkinkan peserta didik- peserta didik dapat bekerjasama dalam kelompok-kelompok kecil yang heterogen dalam mengerjakan tugas.

Jigsaw adalah tipe pembelajaran kooperatif yang dikembangkan oleh Elliot Aronson dan teman-temannya di Universitas Texas pada tahun 1978 (Hamdayama, 2014: 87). Arti jigsaw dalam bahasa Inggris adalah gergaji ukir dan ada juga yang menyebutkan dengan istilah puzzle yaitu sebuah teka-teki menyusun potongan gambar. Pembelajaran kooperatif model jigsaw ini mengambil pola cara bekerja sebuah gergaji (zig zag), yaitu peserta didik melakukan suatu kegiatan belajar dengan cara bekerja sama dengan peserta didik lain untuk mencapai tujuan bersama (Rusman, 2011: 217).

Model pembelajaran ini didesain untuk meningkatkan rasa tanggung jawab peserta didik terhadap pembelajarannya sendiri dan juga pembelajaran orang lain. Peserta didik tidak hanya mempelajari materi yang diberikan, tetapi mereka juga harus siap memberikan dan mengajarkan materi tersebut kepada kelompoknya, sehingga baik kemampuan secara kognitif maupun sosial 
Penerapan Model Pembelajaran Kooperatif Tipe Jigsaw Sebagai Upaya Meningkatkan Prestasi Belajar Muatan PKn Peserta Didik di Kelas VI SDN 96/X Rantau Indah Semester Ganjil Tahun Ajaran 2021/2022, Maryatun

peserta didik sangat diperlukan. Model pembelajaran tipe jigsaw ini dilandasi oleh teori belajar humanistik, karena teori belajar humanistik menjelaskan bahwa pada hakikatnya setiap manusia adalah unik, memiliki potensi individual dan dorongan internal untuk berkembang dan menentukan perilakunya (Hamdayama, 2014: 87).

Model pembelajaran tipe jigsaw, terdapat kelompok ahli dan kelompok asal. Kelompok asal adalah kelompok awal peserta didik terdiri atas beberapa anggota kelompok ahli yang dibentuk dengan memperhatikan keragaman dan latar belakang, sedangkan kelompok ahli yaitu kelompok peserta didik yang terdiri atas anggota kelompok lain (kelompok asal) yang ditugaskan untuk mendalami topik tertentu untuk kemudian dijelaskan kepada anggota kelompok asal. Di sini, peran guru adalah memfasilitasi dan memotivasi para anggota kelompok ahli agar mudah untuk memahami materi yang diberikan. Kunci tipe jigsaw adalah interdependence setiap peserta didik terhadap anggota tim yang memberikan informasi yang diperlukan. Artinya, para peserta didik harus memiliki tanggung jawab dan kerjasama yang positif dan saling ketergantungan untuk mendapatkan informasi dan memecahkan masalah yang diberikan (Hamdayama, 2014: 88).

\section{METODE}

Jenis penelitian ini adalah penelitian tindakan kelas. Penelitian ini dilaksanakan di SDN 96/ X Rantau Indah pada semester ganjil, tahun ajaran 2021/2022. Subjek dalam penelitian ini adalah siswa VI dengan jumlah peserta didik 12 orang. Prosedur penelitian ini meliputi perencanaan, pelaksanaan, pengamatan, dan refleksi. Penelitian ini dilaksanakan dalam dua siklus, masing-masing siklus terdiri dari dua kali pertemuan. Teknik yang digunakan dalam pengumpulan data adalah observasi, tes, catatan lapangan dan dokumentasi. Data dianalisis melalui persentase dan reduksi data.

\section{HASIL DAN DISKUSI}

\section{Siklus I}

\section{Perencanaan}

Pada tahap perencanaan yang dilakukan oleh peneliti adalah Peneliti mempersiapkan silabus, menyusun Rencana Pelaksanaan Pembelajaran (RPP), bahan ajar, Lembar Kerja Peserta didik (LKS), soal evaluasi, rubrik pengamatan keaktifan, menyiapkan kamera, mempersiapkan media pembelajaran dan membagi peserta didik dalam kelompok asal.

\section{Pelaksanaan}

Pembelajaran pada pertemuan pertama dilaksanakan pada hari Kamis tanggal 21 Oktober 2021, sesuai dengan RPP yang sudah dibuat oleh peneliti. Materi yang akan diajarkan kepada peserta didik adalah lembaga-lembaga negara. Pembelajaran hanya diawali dengan salam pembuka saja karena penelitian tidak dilakukan dari awal pembelajaran. Peneliti meminta peserta didik untuk memasang nomer di dada sebelah kiri agar memudahkan observer dalam mengobservasi keaktifan sebelum kegiatan pembelajaran dimulai. Pada RPP yang telah disediakan oleh peneliti, seharusnya 
guru menunjukkan gambar presiden dan wakil presiden sebagai motivasi, akan tetapi saat dilaksanakan penelitian presiden dan wakil presiden masih baru dan sekolah belum mempunyai gambarnya, maka guru hanya menanyakan secara lisan siapa nama presiden yang baru, siapa nama wakilnya, dan apakah tugas-tugas presiden dan wakil presiden yang peserta didik ketahui. Kegiatan pembuka diakhiri dengan menyampaikan tujuan pembelajaran.

Kegiatan pertama yang dilakukan pada kegiatan inti, guru menjelaskan garis besar materi yang akan dipelajari, kemudian dilanjutkan dengan membagi peserta didik ke dalam 3 kelompok yang disebut kelompok asal. Masing-masing kelompok asal terdiri dari 3 peserta didik. Setelah peserta didik duduk bersama dengan kelompok, guru dengan dibantu peneliti membagikan materi-materi yang telah disiapkan. Di kelompok asal, masing-masing peserta didik mendapatkan materi yang berbeda-beda. Di kelompok asal, peserta didik diminta untuk membaca dan memahami materi yang mereka terima. Setelah itu, masing-masing peserta didik diminta untuk mencari teman yang mempunyaimateri yang sama dan membentuk kelompok baru yang disebut kelompok ahli. Kelompok ahli ini terdiri dari 3 peserta didik, berdasarkan 6 sub materi yang dibagikan ke peserta didik. Di kelompok ahli, peserta didik diminta untuk berdiskusi tentang materi yang mereka peroleh, menggaris bawahi poin-poin penting dari materi yang telah didiskusikan. Guru lalu membagikan lembar kerja kelompok ahli agar dikerjakan oleh peserta didik. Peserta didik yang sudah selesai mengerjakan tugas mengumpulkan tugasnya dan kembali ke kelompok asal. Kegiatan selanjutnya di kelompok asal masing- masing peserta didik diminta untuk menjelaskan materi yang telah didiskusikan dalam kelompok ahli, lalu setiap kelompok mendapatkan bagan struktur lembaga- lembaga negara yang masih kosong agar diisi.

Lembar kerja yang sudah diselesaikan oleh peserta didik dipresentasikan di depan kelas, kemudian guru memberikan penjelasan ulang dan penegasan mengenai materi lembaga-lembaga negara yang sudah dipelajari. Guru memberikan kesempatan pada peserta didik untuk bertanya jika ada yang belum jelas. Peserta didik diajak untuk mengambil kesimpulan dari materi yang dibahas dalam presentasi. Pada kegiatan akhir, peserta didik dan guru seharusnya merefleksikan kegiatan pembelajaran hari ini secara lisan, tetapi karena waktu tidak mencukupi maka kegiatan itu tidak dapat dilakukan. Guru kemudian menyampaikan materi yang akan dipelajari pada pertemuan selanjutnya. Kegiatan pembelajaran ditutup dengan doa penutup dan juga salam.

Pertemuan kedua di siklus 1 dilaksanakan pada hari Kamis tanggal 28 Oktober 2021, sesuai dengan RPP yang sudah disiapkan oleh peneliti. Kegiatan pembelajaran pada pertemuan ini hampir sama dengan pertemuan pertama. Kegiatan pembelajaran pada pertemuan kedua ini sesuai dengan RPP yang sudah dibuat oleh peneliti. Materi yang akan diajarkan kepada peserta didik adalah tugas dan wewenang lembaga-lembaga negara. Kegiatan pembelajaran pada pertemuan kedua siklus 1 diawali dengan apersepsi untuk mengetahui sejauh mana pengetahuan peserta didik mengenai tugas dan wewenang ketua kelas. Guru bertanya kepada peserta didik, "apa tugas ketua kelas?”, “apa 
wewenang ketua kelas?", setelah itu guru mengaitkan materi yang akan dipelajari pada hari ini tentang tugas dan wewenang lembaga-lembaga Negara.

Pada kegiatan ini, peserta didik masuk dengan kelompok yang sudah dibuat pada pertemuan pertama. Kelompok ini disebut kelompok asal. Masing-masing kelompok asal terdiri dari 3 peserta didik. Setelah peserta didik duduk bersama dengan kelompok, guru dengan dibantu peneliti membagikan materi-materi yang telah disiapkan. Di kelompok asal, peserta didik mendapatkan materi yang berbeda-beda. Peserta didik diminta untuk membaca dan memahami materi yang mereka terima dan kemudian mencari teman yang mempunyai materi yang sama dan membentuk kelompok baru yang disebut kelompok ahli. Di kelompok ahli, peserta didik diminta untuk berdiskusi tentang materi yang mereka peroleh dan menggaris bawahi poin- poin penting dari materi yang telah didiskusikan. Guru lalu membagikan lembar kerja kelompok ahli agar dikerjakan oleh peserta didik. Tugas yang sudah selesai dikerjakan dikumpulkan dan peserta didik diminta kembali ke kelompok asal. Kegiatan selanjutnya di kelompok asal masing-masing peserta didik diminta untuk menjelaskan materi yang telah didiskusikan dalam kelompok ahli, lalu setiap kelompok mendapatkan tugas membuat ringkasan dalam bentuk mind map tentang tugas dan wewenang lembaga-lembaga negara. Kegiatan selanjutnya adalah mempresentasikan hasil ringkasannya, kemudian guru memberikan penjelasan ulang dan penegasan mengenai materi lembaga-lembaga negara yang sudah dipelajari. Guru memberikan kesempatan pada peserta didik untuk bertanya jika ada yang belum jelas. Peserta didik diajak untuk mengambil kesimpulan dari materi yang dibahas dalam presentasi.

Pada kegiatan akhir pertemuan kedua siklus 1 peserta didik mengerjakan soal evaluasi yang sudah disiapkan oleh guru. Setelah selesai mengerjakan soal evaluasi, peserta didik bersama guru merefleksikan kegiatan pembelajaran pada hari ini secara lisan. Kegiatan pembelajaran ditutup dengan doa penutup dan juga salam.

\section{Observasi}

Keberhasilan proses pembelajaran ditunjukan dengan prestasi belajar peserta didik. Peneliti menggunakan aspek kognitif untuk mengetahui prestasi belajar peserta didik. Kriteria ketuntasan minimal yang ditentukan oleh sekolah untuk mata pelajaran PKn adalah 70. Peneliti menggunakan soal evaluasi yang diberikan di setiap akhir siklus. Soal evaluasi yang digunakan sudah layak digunakan karena sudah divalidasi secara empiris di sekolah yang setara dengan tempat penelitian. Nilai hasil evaluasi peserta didik siklus 1 dapat dilihat pada tabel 1.

Tabel 1. Rekapitulasi hasil tes formatif Siklus I

\begin{tabular}{|c|c|c|}
\hline No & Uraian & Hasil \\
\hline 1 & Jumlah Nilai & 845 \\
\hline 2 & Rata-rata Nilai & 70.42 \\
\hline 3 & Siswa Tuntas & 7 \\
\hline
\end{tabular}




\begin{tabular}{|c|c|c|}
\cline { 2 - 2 } 4 & Siswa Tidak Tuntas & 5 \\
\hline 5 & Persentase Siswa Tuntas & $58 \%$ \\
\hline 6 & Persentase Siswa Tidak Tuntas & $42 \%$ \\
\hline
\end{tabular}

Dari tabel di atas diperoleh nilai rata-rata hasil belajar peserta didik adalah 70,42 dan ketuntasan belajar mencapai $58 \%$ atau ada 7 peserta didik dari 12 peserta didik sudah tuntas belajar.

\section{Refleksi}

Tahap refleksi dilaksanakn pada hari Senin tanggal 1 November 2021 Raden Abdullah, S.Pd bertempat di ruangan majelis guru yang dibantu olh seorang observer yang merupakan guru kelas. Pelaksanaan pembelajaran pertemuan pertama tidak keseluruhan berjalan sesuai rencana. Peserta didik masih banyak yang ribut, tidak mau berkelompok dengan teman yang nilainya rendah di kelas, ketika disuruh pindah dari kelompok asal ke kelompok ahli dan kembali lagi ke kelompok asal ada beberapa peserta didik yang menggerutu. Masih banyak peserta didik yang belum mau untuk mengungkapkan pendapatnya, sehingga kadang-kadang peneliti dan guru perlu untuk melakukan pendampingan.

Prestasi belajar peserta didik terjadi peningkatan rata-rata ulangan harian dari kondisi awal menjadi 58\% di siklus 1 . Peningkatan tersebut sudah memenuhi target capaian yang telah ditentukan oleh peneliti. Jumlah peserta didik yang dapat mencapai KKM juga meningkat. Hal itu terlihat dari jumlah peserta didik yang dapat mencapai KKM meningkat menjadi 7 peserta didik.

Peningkatan keaktifan dan prestasi belajar sudah memenuhi target yang sudah ditentukan oleh peneliti, namun peneliti akan melanjutkan penelitian ke siklus 2. Keputusan untuk melanjutkan ke siklus 2 didasarkan pada pemikiran bahwa peningkatan yang dialami pada siklus 1 benar-benar karena pendekatan kooperatif tipe jigsaw yang digunakan untuk meningkatkan keaktifan dan prestasi belajar peserta didik dalam pembelajaran PKn kelas VI SDN 96/X Rantau Indah, selain itu karena waktu yang ada masih mencukupi untuk melakukan penelitian pada siklus 2. Pada siklus 1 ini masih ada beberapa hal yang perlu diperbaiki oleh peneliti antara lain perlu lebih banyak waktu untuk bertemu dengan guru sebelum melakukan penelitian, sehingga guru benar-benar paham dengan proses kegiatan pembelajaran dengan metode yang dipakai. Pengelolaan waktu belum sesuai dengan rencana pembelajaran, mengatur tempat duduk, waktu masuk ke dalam kelompok asal, dan perpindahan kelompok asal ke kelompok ahli dan kembali lagi ke kelompok asal membuang waktu yang sangat banyak, sehingga menyebabkan pertemuan pertama melebihi waktu yang ditentukan. Oleh karena itu penelitian ini dilanjutkan ke siklus berikutnya.

\section{Siklus II}

\section{Perencanaan}

Pada tahap perencanaan yang dilakukan oleh peneliti adalah Peneliti mempersiapkan silabus, menyusun Rencana Pelaksanaan Pembelajaran (RPP), bahan ajar, Lembar Kerja Peserta didik (LKS), 
Penerapan Model Pembelajaran Kooperatif Tipe Jigsaw Sebagai Upaya Meningkatkan Prestasi Belajar Muatan PKn Peserta Didik di Kelas VI SDN 96/X Rantau Indah Semester Ganjil Tahun Ajaran 2021/2022, Maryatun

soal evaluasi, rubrik pengamatan keaktifan, menyiapkan kamera, mempersiapkan media pembelajaran dan membagi peserta didik dalam kelompok asal.

\section{Pelaksanaan}

Pertemuan pertama pada siklus kedua ini dilaksanakan pada hari Kamis tanggal 11 November 2021 dengan berpedoman pada RPP yang telah dibuat oleh peneliti. Materi yang akan dibahas dalam pertemuan yang pertama adalah lembaga pemerintah pusat. Kegiatan pembelajaran pada pertemuan pertama siklus kedua ini diawali dengan apersepsi dalam bentuk pertanyaan. Guru bertanya“siapa nama presiden dan wakil presiden yang sekarang ini? dimana tempat tinggalnya?", kemudian guru meyampaikan tujuan serta kegiatan yang akan dilakukan dalam pembelajaran.

Kegiatan inti guru menjelaskan garis besar materi yang akan dipelajari, kemudian dilanjutkan dengan membagi peserta didik ke dalam 3 kelompok yang disebut kelompok asal. Masing-masing kelompok asal ini terdiri dari 3 peserta didik. Peserta didik diminta duduk bersama dengan kelompok, kemudian guru dengan dibantu peneliti membagikan materi-materi yang telah disiapkan. Di kelompok asal, peserta didik mendapatkan materi yang berbeda-beda. Peserta didik diminta untuk membaca dan memahami materi yang diterima, kemudian mencari teman yang mempunyai materi yang sama dan membentuk kelompok baru yang disebut kelompok ahli. Di kelompok ahli, peserta didik diminta untuk berdiskusi tentang materi yang mereka peroleh dan menggarisbawahi poin-poin penting dari materi yang telah didiskusikan. Guru lalu membagikan lembar kerja kelompok ahli agar dikerjakan oleh peserta didik. Setelah selesai dikerjakan, tugas dikumpulkan dan peserta didik diminta kembali ke kelompok asal. Kegiatan selanjutnya di kelompok asal masing-masing peserta didik diminta untuk menjelaskan materi yang telah didiskusikan dalam kelompok ahli, lalu setiap kelompok mendapatkan selembar kertas manila yang akan digunakan untuk membuat ringkasan dalam bentuk mind map. Mind map kemudian dipresentasikan di depan kelas. Guru memberikan penjelasan ulang dan penegasan mengenai materi lembaga pemerintah pusat yang sudah dipelajari. Guru memberikan kesempatan pada peserta didik untuk bertanya jika ada yang belum jelas.

Pada kegiatan akhir, peserta didik diajak untuk mengambil kesimpulan dari materi yang dibahas dalam presentasi.Peserta didik dan guru seharusnya merefleksikan kegiatan pembelajaran secara lisan, tetapi karena waktu tidak mencukupi maka kegiatan itu tidak dilakukan. Guru kemudian menyampaikan materi yang akan dipelajari pada pertemuan selanjutnya, yaitu lembaga pemerintah daerah dan juga hubungan lembaga pemerintah pusat dan daerah. Kegiatan pembelajaran ditutup dengan doa penutup dan juga salam.

Pertemuan kedua di siklus 2 ini dilaksanakan pada hari Kamis tanggal 18 November 2021 sesuai dengan RPP yang sudah dibuat oleh peneliti. Kegiatan pembelajaran pada pertemuan kedua hampir sama dengan pertemuan pertama. Perbedaan ada di materi yang dibahas dan pada akhir kegiatan pertemuan kedua siklus kedua ini adalah akhir kegiatan adalah pemberian soal evaluasi. Soal evaluasi dibuat untuk mengetahui peningkatan prestasi belajar peserta didik. Materi yang akan diajarkan kepada peserta didik adalah tugas dan wewenang lembaga-lemb Kegiatan pembelajaran 
pada pertemuan pertama siklus kedua ini diawali dengan apersepsi untuk menggali pengetahuan peserta didik tentang pemerintah daerah yang peserta didik ketahui, seperti "Siapa nama bupati di daerahmu?"; "Dimana kedudukannya?"; "Siapa nama gubernur di daerahmu?"; "Dimana kedudukan gubernur?". Guru juga mengajak peserta didik untuk melakukan tepuk semangat agar peserta didik siap dalam mengikuti pembelajaran. Kegiatan awal diakhiri dengan guru yang meyampaikan tujuan serta kegiatan yang akan dilakukan dalam pembelajaran.

Kegiatan inti guru menjelaskan garis besar materi yang akan dipelajari, kemudian dilanjutkan dengan membagi peserta didik ke dalam 3 kelompok yang disebut kelompok asal. Masing-masing kelompok asal ini terdiri dari 3 peserta didik. Peserta didik diminta duduk bersama dengan kelompok, kemudian guru dengan dibantu peneliti membagikan materi-materi yang telah disiapkan. Di kelompok asal, peserta didik mendapatkan 4 sub materi yang berbeda-beda. Peserta didik diminta untuk membaca dan memahami materi yang diterima, kemudian mencari teman yang mempunyai materi yang sama dan membentuk kelompok baru yang disebut kelompok ahli. Kelompok ahli terdiri dari 5 peserta didik dengan materi yang sama. Di kelompok ahli, peserta didik diminta untuk berdiskusi tentang materi yang mereka peroleh dan menggarisbawahi poin-poin penting dari materi yang telah didiskusikan. Guru lalu membagikan lembar kerja kelompok ahli agar dikerjakan oleh peserta didik. Setelah selesai dikerjakan, tugas dikumpulkan dan peserta didik diminta kembali ke kelompok asal. Kegiatan selanjutnya di kelompok asal masing-masing peserta didik diminta untuk menjelaskan materi yang telah didiskusikan dalam kelompok ahli, lalu setiap kelompok mendapatkan selembar kertas manila yang akan digunakan untuk membuat ringkasan dalam bentuk mind map. Mind map kemudian dipresentasikan di depan kelas. Guru memberikan penjelasan ulang dan penegasan mengenai materi lembaga pemerintah pusat yang sudah dipelajari. Guru memberikan kesempatan pada peserta didik untuk bertanya jika ada yang belum jelas.

Pada kegiatan akhir pertemuan kedua siklus 2 peserta didik mengerjakan soal evaluasi yang sudah disiapkan oleh guru. Setelah selesai mengerjakan soal evaluasi, peserta didik bersama guru merefleksikan kegiatan pembelajaran pada hari ini secara lisan. Kegiatan pembelajaran ditutup dengan doa penutup dan juga salam.

\section{Observasi}

Kegiatan pengamatan pada penelitian ini dilakukan untuk mengamati keaktifan peserta didik kelas VI SDN 96/X Rantau Indah pada saat kegiatan pembelajaran berlangsung. Peneliti dibantu oleh teman sejawat dalam mengamati keaktifan peserta didik di kelas. Keberhasilan proses pembelajaran ditunjukan dengan prestasi belajar peserta didik. Peneliti menggunakan aspek kognitif untuk mengetahui prestasi belajar peserta didik. Kriteria ketuntasan minimal yang ditentukan oleh sekolah untuk mata pelajaran PKn adalah 70. Peneliti menggunakan soal evaluasi yang diberikan di setiap akhir siklus. Soal evaluasi yang digunakan sudah layak digunakan karena sudah divalidasi secara empiris di sekolah yang setara dengan tempat penelitianNilai hasil evaluasi peserta didik siklus 2 dapat dilihat pada tabel 4.2 
Tabel 2. Rekapitulasi hasil tes formatif Siklus II

\begin{tabular}{|c|c|c|}
\hline No & Uraian & Hasil \\
\hline 1 & Jumlah Nilai & 925 \\
\hline 2 & Rata-rata Nilai & 77.08 \\
\hline 3 & Siswa Tuntas & 10 \\
\hline 4 & Siswa Tidak Tuntas & 2 \\
\hline 5 & Persentase Siswa Tuntas & $83 \%$ \\
\hline 6 & Persentase Siswa Tidak Tuntas & $17 \%$ \\
\hline
\end{tabular}

Dari tabel di atas diperoleh nilai rata-rata hasil belajar peserta didik adalah 77,08 dan ketuntasan belajar mencapai $83 \%$ atau ada 10 peserta didik dari 12 peserta didik sudah tuntas belajar.

\section{Refleksi}

Tahap refleksi siklus II dilaksanakan pada hari Senin tanggal 29 November 2021 bersama seorang observer bernama Raden Abdullah, S.Pd bertempat di ruangan majelis guru SDN 96/X Rantau Indah yang dibantu oleh seorang observer yang merupakan guru kelas. Pelaksanaan pembelajaran pada siklus 2 sudah lebih baik daripada siklus 1 . Peserta didik sudah mulai terbiasa dengan model pembelajaran yang diterapkan dan peserta didik juga sudah mulai beradaptasi dengan kelompok. Peserta didik sudah mulai tergugah untuk mau mengemukakan pendapat ataupun bertanya tentang materi yang belum jelas. Peningkatan tersebut sudah memenuhi target yang sudah ditentukan oleh peneliti. Pada prestasi belajar terjadi peningkatan rata-rata nilai ulangan harian PKn dari siklus 1 sebesar 70,42 menjadi 77,08. Peningkatan tersebut sudah memenuhi target capaian yang telah ditentukan oleh peneliti. Selain terjadi peningkatan pada rata-rata nilai ulangan PKn, jumlah siwa yang mencapai KKM pada siklus 1 sebanyak 7 peserta didik meningkat menjadi 10 peserta didik di siklus 2. Jika dipresentasekan sebesar 58\% pada siklus 1 dan meningkat menjadi $83 \%$ di siklus 2 . Berdasarkan hasil diskusi di atas dapat dilihat bahwa peningkatan terjadi dari siklus I ke siklus II dengan penerapan model pembelajaran kooperatif tipe jigsaw. Untuk itu penelitian ini dianggap sudah berhasil dan tidak dilanjutkan ke siklus berikutnya.

\section{Diskusi}

Secara umum, setelah dilakukan pengamatan, prestasi belajar peserta didik memang masih rendah. Hal ini disebabkan oleh tingkat keeaktifan peserta didik yang rendah pula saat mengikuti pembelajaran PKn. Peneliti menerapkan pembelajaran kooperatif tipe jigsaw untuk meningkatkan keaktifan dan prestasi belajar peserta didik dalam pembelajaran. Tingkat prestasi belajar peserta didik yang dilihat dalam penelitian ini adalah jumlah peserta didik yang mampu mencapai KKM. tabel pencapaian penelitian beruapa keaktifan dan prestasi belajar peserta didik mulai dari kondisi awal, siklus 1 , dan siklus 2 .

Hasil keaktifan peserta didik ini dapat berpengaruh pada hasil prestasi belajar peserta didik seperti yang diungkapkan oleh Zaini (2010) yang mengatakan bahwa peserta didik yang pasif, hasil 
belajarnya tidak maksimal. Peserta didik yang mengalami penurunan nilai dimungkinkan karena beberapa faktor yaitu pelajaran diadakan setelah istirahat, sehingga peserta didik sudah merasa lelah dan tidak dapat mengerjakan soal dengan maksimal. Hal ini sependapat dengan pendapat Slameto (2003) tentang faktor- faktor yang mempengaruhi prestasi belajar peserta didik. Faktor-faktor yang mempengaruhi prestasi belajar peserta didik salah satunya faktor eksternal dan faktor internal. Faktor kelelahan merupakan faktor internal peserta didik.

Kesimpulan dari penelitian yang telah dilakukan oleh peneliti melalui model pembelajaran kooperatif tipe jigsaw mampu meningkatkan keaktifan dan prestasi belajar PKn peserta didik kelas VI SDN 96/X Rantau Indah. Hal ini dapat terjadi karena dengan model pembelajaran kooperatif tipe jigsaw dapat melatih peserta didik untuk lebih aktif dan berpendapat, serta peserta didik dapat lebih cepat menguasai materi dalam waktu yang singkat (Hamdayama, 2014). Penerapan model pembelajaran kooperatif tipe jigsaw juga dapat meningkatkan prestasi belajar dan meningkatkan daya ingat peserta didik (Rusman, 2011). Selain itu penerapan model pembelajaran kooperatif tipe jigsaw juga dapat mempermudah pekerjaan guru dalam mengajar, karena sudah ada kelompok ahli yang bertugas menjelaskan materi kepada teman-temannya (Hamdayama, 2014). Dengan demikian keaktifan peserta didik mampu meningkatkan prestasi belajar peserta didik.

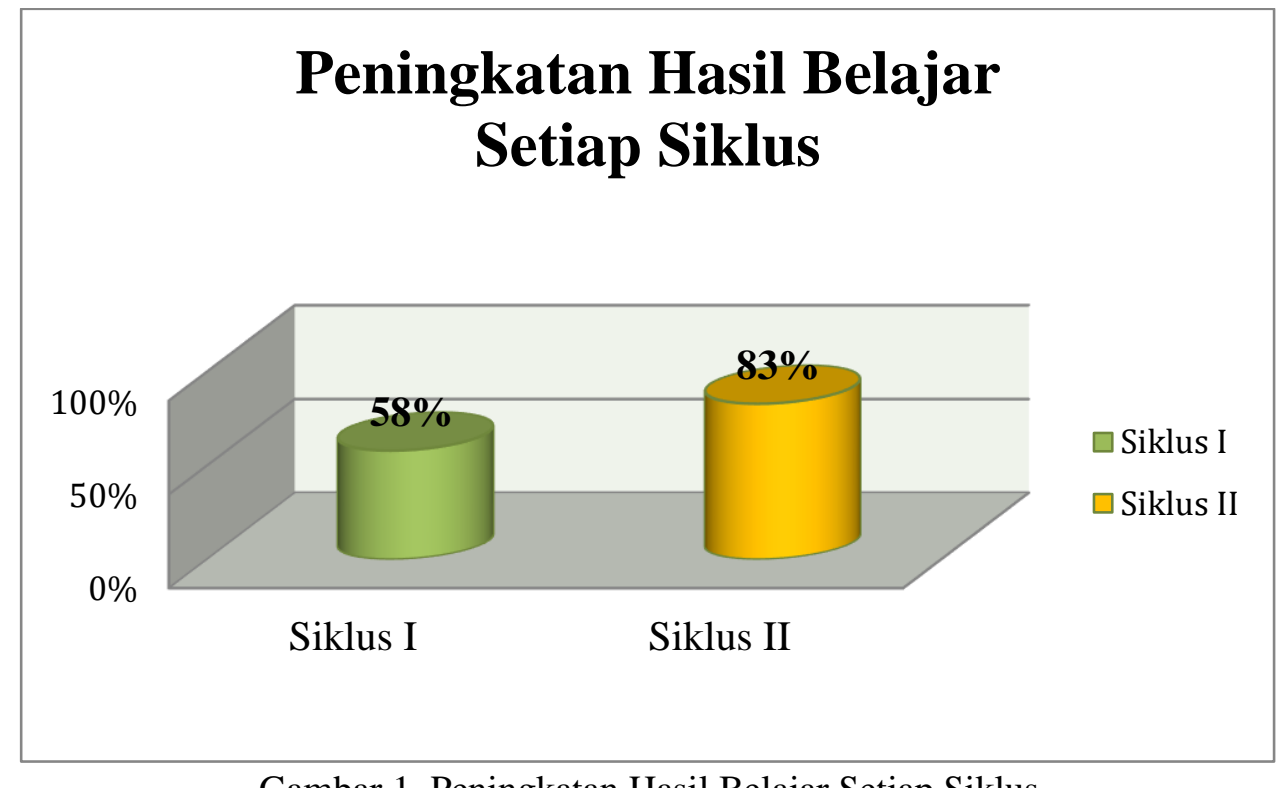

Gambar 1. Peningkatan Hasil Belajar Setiap Siklus

\section{KESIMPULAN}

Berdasarkan hasil penelitian dan pembahasan yang telah dijelaskan pada bab sebelumnya maka dapat disimpulkan bahwa melalui model pembelajaran kooperatif tipe jigsaw dapat meningkatkan keaktifan peserta didik dan prestasi belajar peserta didik kelas VI SDN 96/X Rantau Indah, hal ini ditandai dengan adanya peningkatan rata-rata belajar dan persentase ketuntasan belajar dari siklus I ke siklus II 58\% menjadi 83\%. 
Penerapan Model Pembelajaran Kooperatif Tipe Jigsaw Sebagai Upaya Meningkatkan Prestasi Belajar Muatan PKn Peserta Didik di Kelas VI SDN 96/X Rantau Indah Semester Ganjil Tahun Ajaran 2021/2022, Maryatun

Saran yang dapat disampaikan peneliti berdasarkan penelitian yang telah dilaksanakan yaitu menggunakan ruang kelas yang cukup luas untuk membentuk kelompok dan perpindahan kelompok agar peserta didik lebih nyaman dan tidak berdesak- desakan serta ada jarak antar kelompok yang satu dengan kelompok lainnya. Bagi guru yang menggunakan model pembelajaran kooperatif tipe jigsaw ini sebaiknya dipersiapkan secara matang dan memperhitungkan alokasi waktu agar pembelajaran dapat berjalan dengan lancar dan tepat waktu. Selain itu juga mengenalkan terlebih dahulu pada peserta didik tentang model pembelajaran yang akan dilaksanakan supaya peserta didik tidak merasa kebingungan dan peserta didik mampu memahami pembelajaran yang diberikan guru dengan baik.

\section{REFERENSI}

Asmani, Amal Ma'mur. 2011. Tips Pintar PTK: Penelitian Tindakan Kelas. Yogyakarta: Laksana.

Astuti, Sari. 2013. Upaya Meningkatkan Keaktifan Belajar Peserta didik Melalui Cooperative Learning Jigsaw Pada Mapel IPS Kelas VIII SMP Negri 1 Puring Kab. Kebumen. Purworejo: Universitas Muhamadiyah.

Arifin, Z. 2013. Evaluasi Pembelajaran. Bandung: PT Remaja Rosdakarya. Arikunto, Suharsimi. 2010. Prosedur penelitian suatu pendekatan praktik. Jakarta: Rineka Cipta.

BSNP. 2006. Standar Isi untuk Satuan Pendidikan Dasar dan Menengah, Standar Kompetensi dan Kompetensi Dasar SD/MI. Jakarta: BSNP.

Darmadi, Hamid. 2010. Pengantar Pendidikan Kewarganaegaraan. Bandung: Alfabeta

Departemen Pendikan Nasional. 2008. Kamus Besar Bahasa Indonesia. Jakarta: Gramedia

Djamarah, Syaiful Bahri. 2011. Psikologi Belajar. Jakarta: Rineka Cipta Dimyati dan Mudjiono. 2009. Belajar dan Pembelajaran. Jakarta: Rineka Cipta

Hamdayana, Jumanta. 2014. Model dan Metode Pembelajaran Kreatif dan Berkarakter. Bogor: Ghalia Indonesia.

Harmianto, dkk. 2011. Model-Model Pembelajaran Inovatif dan Efektif. Bandung: Alfabeta.

Indratno, Ferry T. 2009. Ayo Belajar PKn 5. Yogyakarta: Kanisius

Jihad dan Haris. 2011. Evaluasi Pembelajaran. Yogyakarta: Multipresindo

Kunandar. 2008. Langkah Mudah Penelitian Tindakan Kelas Sebagai Pengembangan Profesi Guru. Jakarta: PT Raja Grafindo Persada.

Kusumah dan Dwitagama. 2010. Mengenal Penelitian Tindakan Kelas. Jakarta: PT Indeks

Lie, Anita. 2007. Cooperative Learning: Mempraktikan Cooperative Learning di Ruang-ruang Kelas.

Jakarta: Gramedia Widiasarana Indonesia.

Margono. 2003. Metodologi Penelitian Pendidikan. Jakarta: Rineka Cipta Masidjo, Ign. 2006. Penilaian Pencapaian Hasil Belajar Peserta didik di Sekolah. Yogyakarta: Kanisius.

Masriyah, Siti. 2012. Penerapan Pembelajaran Kooperatif Tipe Jigsaw Untuk Meningkatkan Hasil Belajar Peserta didik Kelas IV Pada Pelajaran IPA. Cirebon: Jakarta: Universitas Islam Negeri Syarif Hidayattulah. 
Mulyasa, E. 2006. Implementasi Kurikulum 2004 Panduan Pembelajaran KBK. Bandung: PT Remaja Rosdakarya.

Pardjono, dkk. 2007. Panduan Penelitian Tindakan Kelas. Laporan Penelitian; UNY

Purnomo, Puji. 2006. Model Pembelajaran Tematik Sekolah Awal SD. Pusat Bahan Penelitian Pengembangan Departemen Pendidikan Nasional.

Purwanto. 2009. Evaluasi Hasil Belajar. Yogyakarta: Pustaka Pelajar.

Rahayu, Setyo Dwi. 2010. Penerapan Model Pembelajaran Jigsaw Untuk Meningkatkan Hasil Belajar PKn bagi Peserta didik Kelas IV SDN Pisang Kabupaten Nganjuk. Surabaya: Universitas Muhamadiyah.

Rosdijati, dkk. 2010. Panduan PAKEM IPS SD. Jakarta: Erlangga

Rusman. 2010. Model-model Pembelajaran. Jakarta: PT. Raja Grafindo Persada Rusman. 2011. Model-model Pembelajaran Pengembangan Profesionalisme Guru. Jakarta: PT. Raja Grafindo Persada

Sanjaya, Wina. 2006. Strategi Pembelajaran: Berorientasi Standar Proses Pendidikan. Jakarta: Kencana Prenada Group

Sardiman. 2001. Interaksi dan Motivasi Belajar Mengajar. Jakarta: PT Raja Grafindo Persada.

Slameto. 2010. Belajar dan Faktor-Faktor yang Mempengaruhinya. Jakarta: Rineka Cipta

Solihatin, Etin 2007. Cooperative Learning Analisis Model Pembelajaran IPS. Jakarta: Bumi Aksara.

Sudjana. 2010. Penilaian Hasil Proses Belajar Mengajar. Jakarta: PT Remaja Rosdakarya.

Sudijono, Anas. 2009. Pengantar Evaluasi Pendidikan. Jakarta: Rajawali Pers. Sugiyanto. 2010. Model-model Pembelajaran Inovatif. Surakarta: Yuma Pustaka Sugiyono. 2008. Statistika Untuk Penelitian. Bandung: Alfabeta

Sugiyono. 2010. Metode Penelitian Kuantitatif, Kualitatif, dan R\&D. Bandung: Alfabeta

Sugiyono. 2011. Metode Penelitian ～Kombinasi Mixed Methods). Bandung: Alfabeta.

Sunarso, dkk. 2006. Pendidikan Kewarganegaraan Buku Pegangan Mahapeserta didik Paradigma Baru. Yogyakarta: UNY Press. 